\title{
Assessing the Impact of Instructional Methods and Information Technology on Student Learning Styles
}

\author{
Poonam Kumar \\ Saginaw Valley State University \\ Saginaw, MI, USA
}

pkumar@svsu.edu

\begin{abstract}
Anil Kumar and Karl Smart
Central Michigan University

Mount Pleasant, MI, USA
\end{abstract}

\author{
anil.kumar@cmich.edu \\ karl.smart@cmich.edu
}

\begin{abstract}
In an era of increased accountability in assessing student learning outcomes, greater emphasis has been focused on factors that influence student learning. In this paper we examine the impact of instructional methods and information technology on student learning styles, all critical factors affecting student learning. A research framework that suggests the relationship of instructional processes and information technology to learning styles is proposed. Using the framework, preand post-tests based on the Grasha-Riechmann Student Learning Styles Scales were used to assess changes in student learning styles over the course of a semester in three college-level courses. Through specific instructional intervention coupled with collaborative projects and the use of course-management software, the results of the assessments showed a significant increase in students' Collaborative, Participant, and Independent learning styles over the course of the semester. Implications for practice and additional research are suggested.
\end{abstract}

Keywords: Learning styles, Information technology, Instructional Methods, Grasha-Riechmann Student Learning Styles Scales, Impact on Student learning styles

\section{Introduction}

The current outcome-based educational environment has brought an increased emphasis on understanding and enhancing the teaching-learning process. Instructional methods and student learning styles are the two critical factors that play a major role in the teaching-learning process. Understanding learning styles and the interaction between various instructional methods and learning styles can increase our understanding of the teaching-learning process and help us in enhancing it. In addition, technology can be a very valuable tool in customizing instruction for diverse student needs and learning preferences.

Several reasons exist why we should incorporate learning style information in our teaching. Since

Material published as part of this journal, either on-line or in print, is copyrighted by Informing Science. Permission to make digital or paper copy of part or all of these works for personal or classroom use is granted without fee provided that the copies are not made or distributed for profit or commercial advantage AND that copies 1) bear this notice in full and 2) give the full citation on the first page. It is permissible to abstract these works so long as credit is given. To copy in all other cases or to republish or to post on a server or to redistribute to lists requires specific permission from the publisher at Publisher@InformingScience.org today's student population continues to grow more diverse (non-traditional, international students, company executives), an awareness of students' learning styles can help facilitate designing more effective instruction in a way that it is responsive to all students. In turn, this conscious design of instruction will lead to greater student 
satisfaction and achievement (McKeachie, 1995; Montgomery \& Groat, 1998; O’ Connor, 1997). A traditional approach of "one size fits all" can lead to student frustration, boredom, and failure.

According to Felder (1993, p. 286):

Students whose learning styles are compatible with the teaching style of a course tend to retain information longer, apply it more effectively, and have more positive post-course attitudes toward the subject than do their counterparts who experience learning/teaching style mismatches.

Additionally, students who understand differences in learning styles can become better learners if they expand their learning preferences in other areas, too (McKeachie, 1995; O' Connor, 1997). The success of learning depends, in part, on adapting teaching for individual learning styles (Corno \& Snow, 1986). Despite research that shows that students learn in different ways and individual differences influence learning, very few instructors design their instruction to accommodate differences in learning styles (Farrington, 1999). Further, very few instructors incorporate both instructional methods and information technology to support diverse learning styles (O’Connor, 1997).

Most research in this area so far has focused either on teaching styles or learning styles or on technology. This paper provides an integrated approach and describes a process of integrating all three dimensions - instructional methods, learning styles, and information technology-in the teaching-learning context. This study examines the impact of instructional strategy and information technology on student learning styles.

\section{Conceptual Framework}

The research framework we use in this study has been adapted from the technology-mediated learning framework proposed by Alavi and Leidner (2001). Alavi and Leidner emphasize that in order to get a deeper understanding of the role of information technology in teaching-learning processes, we need to consider other factors like instructional methods and psychological learning processes of students. Psychological learning processes refer to how students learn and process information. In this study, we use the construct of learning styles to help us understand how different students process and learn information. Alavi and Leidner (2001) recommend that research is needed to examine the interactions between information technology, instructional methods, and the psychological processes of students. This paper attempts to fill this gap in student learning styles research by examining the impact of instructional methods and information technology on learning styles of students. Figure 1 shows the conceptual framework for the study. The study examined the impact of instructional methods and information technology on student learning styles and attempted to find out if students learning styles can be changed by combining technology and in-

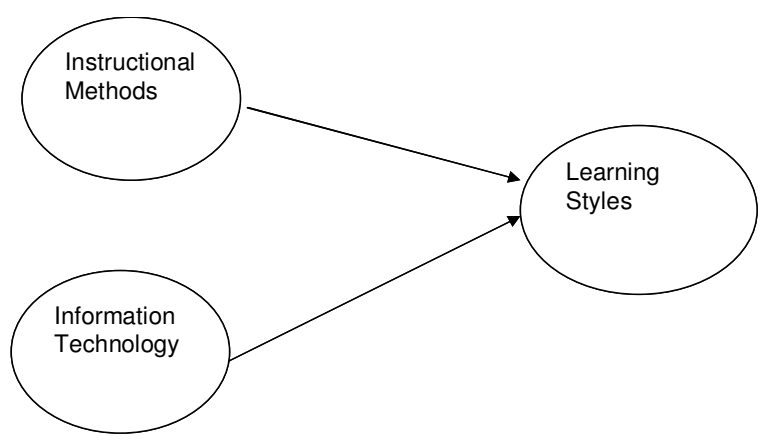

\section{Figure 1. Conceptual Framework for Impact on} Student Learning Styles structional methods.

Based on the literature review, we believe that instructional methods and instructional technology can influence student' learning styles. Grasha (1996) suggests that students' learning styles are 
flexible and can be changed as a result of their experiences in the classroom. For example, if the instructor uses a lot of cooperative learning and requires students to do lot of collaborative assignments, it may strengthen the students' collaborative learning styles. Further, technology is a valuable tool in this teaching-learning process and can be used along with specific instructional methods to promote and strengthen certain learning styles. In the following sections we discuss the individual components of this framework.

\section{Learning Style Models}

Research has shown that people learn in different ways and they have individual preferences of how they perceive and process information. These individual preferences of learning are called learning styles. Grasha (1996, p. 41) defines learning styles as "personal qualities that influence a student's ability to acquire information, to interact with peers and the teacher, and otherwise to participate in learning experiences". Dunn (1986, p. 12) defines learning styles as ways in which an individual "absorbs and retains information or skills". For many years, educators, psychologists, and researchers have been interested in finding out about these individual differences. Several models have been developed to understand and assess the individual learning styles. In this section some of the most commonly used models are discussed.

\section{Kolb/ McCarthy Learning Cycle}

This model is based on the assumption that learning involves a cycle of four learning modes, but each individual is likely to feel most comfortable in one of the four modes of the cycle based on his/her preferences along two dimensions: Perception (Abstract/Concrete) and Processing (Active/Reflective) (Kolb, 1984).

\section{Felder-Silverman Learning Styles Model}

This learning style model was developed by Richard Felder and Linda Silverman (Felder \& Silverman, 1988). According to this model there are five learning style dimensions: Perception (sensing/ intuitive), Processing (active/reflective), Input (visual/ verbal), Organization (inductive/ deductive), and Understanding (sequential/ global).

\section{Grasha-Riechmann Learning Styles}

The learning style model developed by Anthony Grasha and Sheryl Hruska-Riechmann (HruskaReichmann \& Grasha, 1992) uses a different approach from the other learning style models as it is based on how students respond to actual classroom activities rather than an assessment of their personality or cognitive traits. Grasha (1996, p.127) states, "It is important to remember that the styles describe a blend of characteristics that apply to all students. Some learners are simply stronger on some dimensions than others". Grasha believes that students prefer all six of the styles to some extent but they may have a stronger preference for one particular learning style. The six main styles in the Grasha-Reichmann Student Learning Style Scales (GRSLSS) are described:

1. Independent students prefer self-pace instruction and prefer to study alone rather than with other students. They like to think for themselves and are confident in their abilities. They like maximum choice and flexibility and minimum of structure and form. They prefer independent assignments and self-paced instruction.

2. Dependent students prefer that the teacher guides them and tells them what to do. They only learn what is required and they look up to the teacher for specific guidelines on what to do. They show little intellectual curiosity. They prefer outlines, clear instructions and guidelines and teacher-centered classroom activities. 
3. Competitive students learn in order to perform better than their peers. They feel that they have to compete with other students in the class to get a grade. They like to be the center of attention and to receive recognition for their academic achievements.

4. Collaborative learners learn by sharing and cooperating with their teachers and peers. They prefer lectures with small group discussions and group projects.

5. Avoidant learners are not enthusiastic about attending class or acquiring class content. They don't like to participate in class activities and are sometimes overwhelmed by class activities.

6. Participant learners are interested in class activities and discussions. They enjoy coming to class and participating in class activities. They like opportunities to discuss class material and readings.

This study uses the GRSLSS because this approach to learning style provides an integrated model of teaching and learning, providing a method of focusing on and assessing teaching strategies for both teaching strategies and learning styles. Grasha (1996) has also developed teaching styles and instructional methods associated with each learning style. He provides suggestions on how instructors can create "matches" and "mismatches" in the classroom to accommodate different learning styles and to help students expand their learning styles in other areas. Table 1 shows the six learning styles and indicates what score from

Table 1. Grasha-Reichmann's Learning Styles and Classification as Low, Moderate, or High

\begin{tabular}{|c|c|c|c|}
\hline$\frac{\text { Learning }}{\underline{\text { Style }}}$ & Low & $\underline{\text { Moderate }}$ & High \\
\hline Independent & 1.0 to 2.7 & 2.8 to 3.8 & 3.9 to 5.0 \\
\hline Avoidant & 1.0 to 2.7 & 2.8 to 3.4 & 3.5 to 5.0 \\
\hline Collaborative & 1.0 to 2.9 & 3.0 to 4.0 & 4.1 to 5.0 \\
\hline Dependent & 1.0 to 2.9 & 3.0 to 4.0 & 4.1 to 5.0 \\
\hline Competitive & 1.0 to 1.7 & 1.8 to 2.8 & 2.9 to 5.0 \\
\hline Participant & 1.0 to 3.0 & 3.1 to 4.1 & 4.2 to 5.0 \\
\hline
\end{tabular}
the assessment is considered low, moderate, or high.

\section{Instructional Methods}

Just as different ways of learning exist among students, similarly instructors have different ways of teaching. According to Grasha (1996), teaching styles can be categorized into four main clusters, with primary and secondary styles or emphases in each cluster. Table 2 shows the four teaching clusters Grasha identifies, suggesting the primary roles and activities instructors adhere to. Instructors may exhibit more than one teaching style just as students rely on multiple learning preferences; however, in both instances dominant preferences generally exist. As instructors become aware of their own

\begin{tabular}{|c|c|}
\hline \multicolumn{2}{|c|}{ Table 2. Grasha's Four Main Teaching Clusters } \\
\hline Cluster 1 & Cluster 2 \\
\hline Primary Styles & Primary Styles \\
Expert/Formal Authority & Personal Model/Expert/Formal \\
Secondary Styles & Authority \\
Personal & Secondary Styles \\
Model/Facilitator/Delegator & Facilitator/Delegator \\
\hline Cluster 3 & Cluster 4 \\
\hline Primary Styles & Primary Styles \\
Facilitator/ Personal & Delegator/ Facilitator/Expert \\
Model/Expert & Secondary Styles \\
Secondary Styles & Formal Authority/Personal \\
Formal Authority/ & Model \\
Delegator & \\
\hline
\end{tabular}
dominant teaching styles, they may then look at developing instructional activities more demonstrative of other styles, ones targeted to specific learning styles of students. 
Grasha (1996) suggests that instructors can use an integrated model of the teaching and learning styles to plan a variety of instructional methods for creating creative "matches" and mismatches." Grasha believes that while students have certain learning preferences, these preferences can change depending on classroom instruction. Specifically, instructors can use Grasha's model for two purposes.

First, instructors can plan activities to accommodate particular learning styles. For example, group projects and small group discussions accommodate students who have collaborative learning preference. Similarly, lectures accommodate dependent learners in the classroom; independent assignments support students with independent learning styles. A study conducted by Andrews (1981) — as cited in Grasha (1996) — shows that students with a certain learning style prefer certain activities. Andrews shows that students with strong "personal" styles (Collaborative, Participant, Dependent) prefer peer-centered learning and group discussions. Students with more "impersonal" styles (Independent, Avoidant, Competitive) like the texts, handouts, and lectures.

Second, instructors can use learning style information to design courses to provide creative mismatches between the instructional processes and the student learning styles. This approach will help students expand their learning preferences in less dominant areas. Grasha (1996, p. 127) believes that "Not only does such stretching help to build their competency with different styles, it teaches valuable skills that may transfer to other settings including jobs". For example, having group projects and activities in the classroom will encourage students with an Independent learning style to strengthen their Collaborative learning style. Similarly, having individual and selfdirected assignments can encourage students to develop their Independent learning style. In this study we used instructional methods that would help students strengthen their Independent, Collaborative and Participant learning styles

\section{Information Technology}

When information technology is used thoughtfully in combination with instructional methodskeeping in mind differences in learning styles - technology can become a valuable tool in individualizing instruction for various learning styles (O’ Connor, 1997; Ross \& Schultz, 1999; Soles $\&$ Moler, 2001). For example, technology can be used to present information in multiple formats - video clips, animation, graphics, audio files - to make instruction appropriate for Independent or other learners who rely on visual and auditory cues in learning (Ross \& Schultz, 1999). Similarly, placing lectures on the course website can be very helpful for those students who need more time to process and internalize the information (Sarasin, 1998).

Furthermore, some students prefer learning by collaborating and interacting their peers (Grasha, 1996). A traditional lecture-based classroom can be boring and frustrating for these students. Email, discussion forms, electronic collaborative projects can be used to enhance interactions and collaboration among students (Sarasin, 1998). Information technology can also be used to support independent learners by giving students additional resources and links so that they can explore the material alone at their pace. Information technology can also be used to encourage student participation. For example, some shy students who might not participate in class may participate in online discussions, helping them develop more collaborative skills.

Undoubtedly, technology has many capabilities that instructors can use to create student-centered learning environments. But technology is only a tool; to use it effectively, the use of technology must be combined with an understanding of the teaching-learning process (O' Connor, 1997). Most studies have only looked at the relationship between either technology and learning styles or technology and student performance. This study combines an analysis of instructional methods and technology as they relate to learning styles to provide a broader perspective. 


\section{Methods and Procedures}

\section{The Participants}

The sample group for this study included 65 students enrolled in three classes. Two of the classes were Special Education Methods classes (combined graduate and undergraduate students) and one class was an introductory IT course, Computers in Business. The classes were taught during a six-week summer session at two medium-sized Midwestern Universities. Forty-eight students were enrolled in the Special Education Methods class and 17 students were enrolled in the IT course. Out of the 65 students, 27 students $(41.5 \%)$ were graduate students and $38(58.5 \%)$ were undergraduate students. Fourteen $(21.5 \%)$ were male students and $51(78.5 \%)$ were female. Students came from a variety of majors, although the majority were education and business majors. (See Figure 2.)
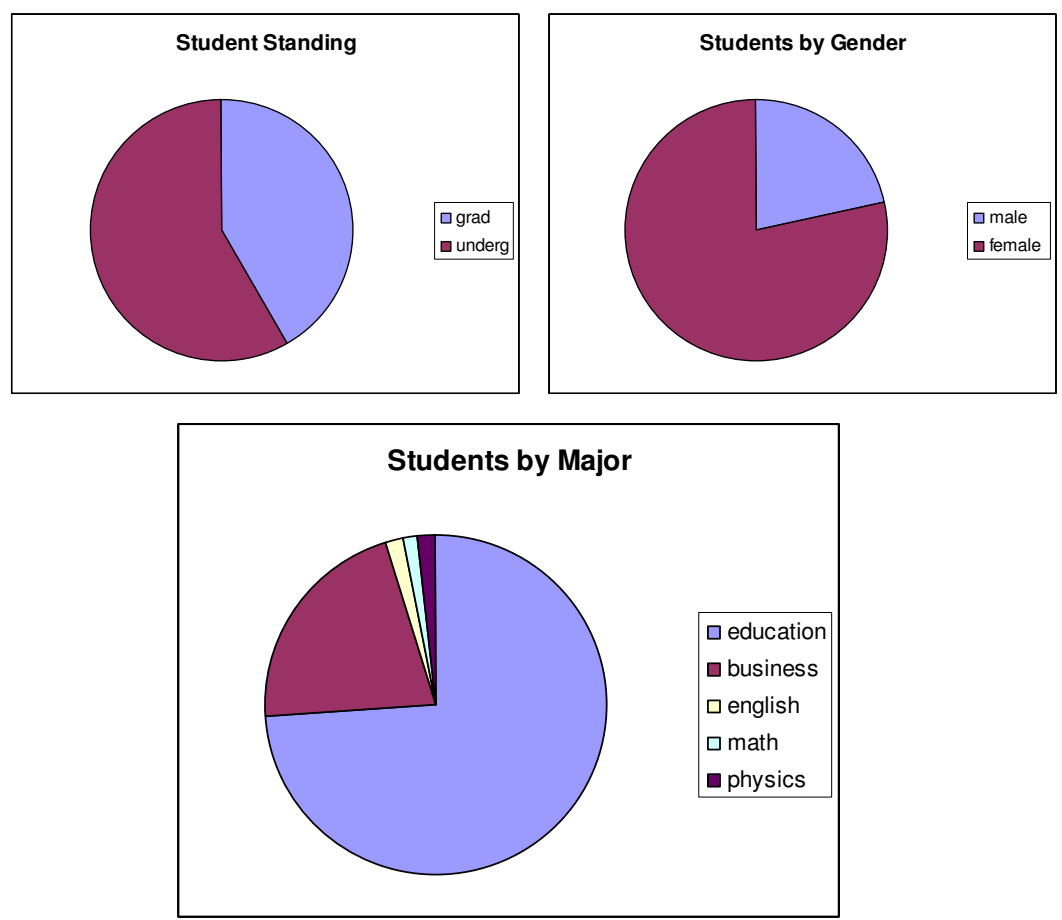

Figure 2. Students by Standing, Gender, and Major

\section{Assessment of Student Learning Styles and Description of Instructional Methods and Technology Used}

For this study, we assessed students' learning styles using the GRSLSS at the beginning of the semester and collected basic demographic data. The initial learning styles inventory data established a baseline from which we could measure any changes in preferences as a result of specific instructional strategies and technology integrated in the courses during the semester. We were specifically interested in seeing if specific instructional strategies along with the appropriate use of technology could affect students' learning styles.

Of the learning styles identified by Grasha (1996), we were specifically interested in measuring changes in the Collaborative, Participant, and Independent preferences of students, hoping to increase student scores in these preference area indicators. Students exhibiting these preferences 
demonstrate characteristics identified as critical to success both in schooling and in the workplace. For instance research suggests students learn better as active participants in their learning, often with the goal of becoming independent learners (Argyris 1991; Bartlett \& Kotrlik 2001; Bonwell \& Eison, 2000; Ellerman, Denning, \& Hanna 2001; Knowles 1975). Additionally, the ability to work collaboratively is critical to success in the workplace, with an increase of crossfunctional teams in many organizations (Glassop, 2002; Michaelsen, Knight, \& Fink, 2003; Sashkin \& Sashkin, 1994; Zemke, 1993).

After the initial assessment using the GRSLSS, we designed specific instructional activities centered around the three targeted learning preference areas. Although we included instructional strategies to accommodate all the preference areas, we planned specific interventions in an attempt to assess if differences in learning styles could be impacted through designing specific instructional strategies.

In addition, an integral part of the course was the use of Blackboard (version 5.5), a course management application distributed and used via the Internet. Both universities where the study was conducted use Blackboard as their standard course management software. Blackboard facilitates the distribution of information electronically and allows students and teachers to communicate through email, threaded discussions, and synchronous chat sessions. Students can post information about themselves, and group areas can be set up to facilitate specific work in teams. Students also have the opportunity to view course notes, slideshows, and handouts that have been posted as well as check scores on assignments in a grade book section (available only to an individual student checking his or her grade).

After implementing the designed instructional interventions while using Blackboard as an integral tool throughout the semester, the GRSLSS was given at the end of the semester to assess any changes in students' learning style preferences relating to the experiences they had had in the class. Table 3 shows the relationship among the various teaching styles, learning styles, and instructional methods outlined by Grasha (1996).

\begin{tabular}{|c|c|}
\hline \multicolumn{2}{|c|}{$\begin{array}{l}\text { Table 3. The Relationship among Teaching Styles, Learning styles, and } \\
\text { Instructional Methods (Grasha, 1996) }\end{array}$} \\
\hline Clus & \\
\hline $\begin{array}{l}\text { Primary Teaching Styles: Expert/ Formal Au- } \\
\text { thority } \\
\text { Primary Learning Styles: Dependent/ Partici- } \\
\text { pant/ Competitive } \\
\text { Instructional Methods Suggested: } \\
\text { - Exams/ Grades Emphasized } \\
\text { - Guest Speakers/ Guest Interviews } \\
\text { - Lectures } \\
\text { - Mini-Lecture + Triggers } \\
\text { - Teacher-Centered Questioning } \\
\text { - Teacher-Centered Discussions } \\
\text { - Tutorials } \\
\text { - Technology-Based Presentation }\end{array}$ & $\begin{array}{l}\text { Primary Teaching Styles: Expert } \\
\text { Primary Learning Styles: Participant/ Depend- } \\
\text { ent/ Collaborative } \\
\text { Instructional Methods Suggested: } \\
\text { - Role Modeling by Illustration } \\
\text { - } \quad \text { Discussing Alternate Ap- } \\
\text { proaches } \\
\text { - } \quad \text { Sharing Thought Processes In- } \\
\text { volved in Obtaining Answers } \\
\text { - } \quad \text { Sharing Personal Experiences } \\
\text { - Role Modeling by Direct Action } \\
\text { - Demonstrating ways of Think- } \\
\text { ing/ } \\
\text { - Doing Things } \\
\text { Having Students Emulate } \\
\text { Teacher } \\
\text { Coaching/ Guiding Students }\end{array}$ \\
\hline
\end{tabular}




\begin{tabular}{|l|l|}
\hline \multicolumn{1}{|c|}{ Cluster 3 } & \multicolumn{1}{c|}{ Cluster 4 } \\
\hline Primary Teaching Styles: Facilitator/ Personal & $\begin{array}{l}\text { Primary Teaching Styles: Delegator/ Facilita- } \\
\text { tor/ Expert }\end{array}$ \\
$\begin{array}{l}\text { Primary Learning Styles: Collaborative/ Par- } \\
\text { ticipant/ Independent }\end{array}$ & $\begin{array}{l}\text { Primary Learning Styles: Independent/ Col- } \\
\text { laborative/ Participant }\end{array}$ \\
Instructional Methods Suggested: & Instructional Methods Suggested: \\
- Case Studies & - Independent Study/ Research \\
- Concept Maps Discussion & - Jigsaw Groups \\
- Critical Thinking Discussion & - Learning Pairs \\
- Kuided Readings & - Sosition Papers \\
- Problem Based Learning & \\
- Lab Projects & \\
\hline
\end{tabular}

Table 4 details the specific instructional activities implemented with the technology to accommodate different learning styles. The specific learning styles corresponding with the instructional interventions are noted.

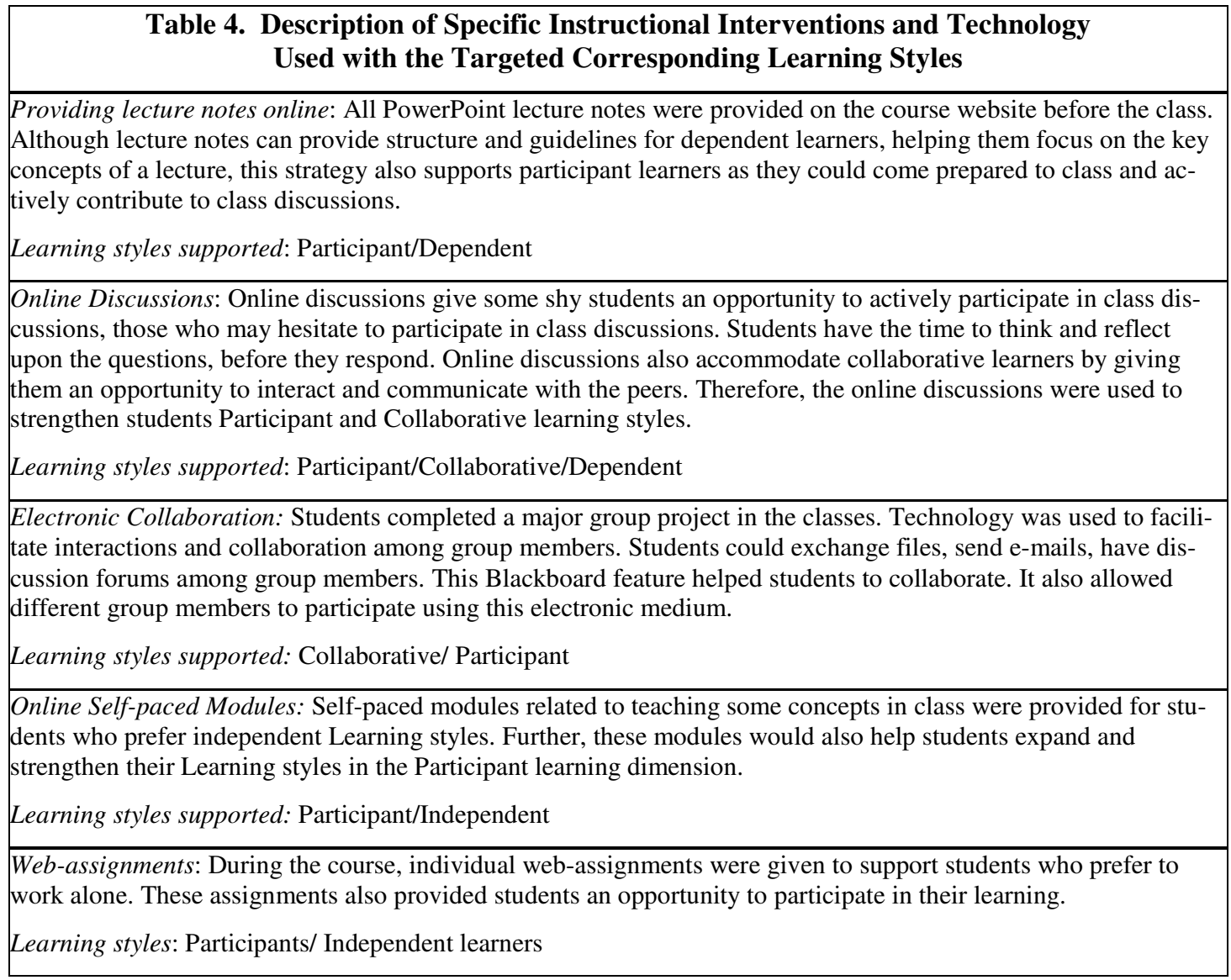


Online Grade Book: Students could view their grades regularly using the grade book feature of Blackboard feature. This gave immediate and regular feedback to students and encouraged them to participate. It also supported the Competitive learners.

Learning styles: Competitive/Participant

Additional Web Resources: Several additional resources related to the course content were provided on the course website. These resources gave the Participant, Competitive, and Independent learners to learn more information related to the content of the course.

Learning styles: Participant/Competitive/Independent

These specific instructional activities, integrated with the pervasive use of Blackboard (the technology), were used to attempt to impact students' learning styles. At the end of the semester, the GRSLSS was then administered on the last day of class to assess the impact of instructional practices and technology on the learning styles of students.

\section{Results}

An analysis of the learning style data at pre-test indicated that students had different learning styles. They scored high on Participant, Collaborative, and Dependent learning styles. This information suggests that most students would have preferred collaborative projects and opportunities to actively participate in the class. They also had a high score on the dependent learning style, suggesting that they would prefer outlines, notes, clear instructions, and some teacher-centered instruction. Their least preferred styles were Avoidant, Competitive, and Independent Learning styles. Differences among graduate, undergraduate, gender, and major were not analyzed because

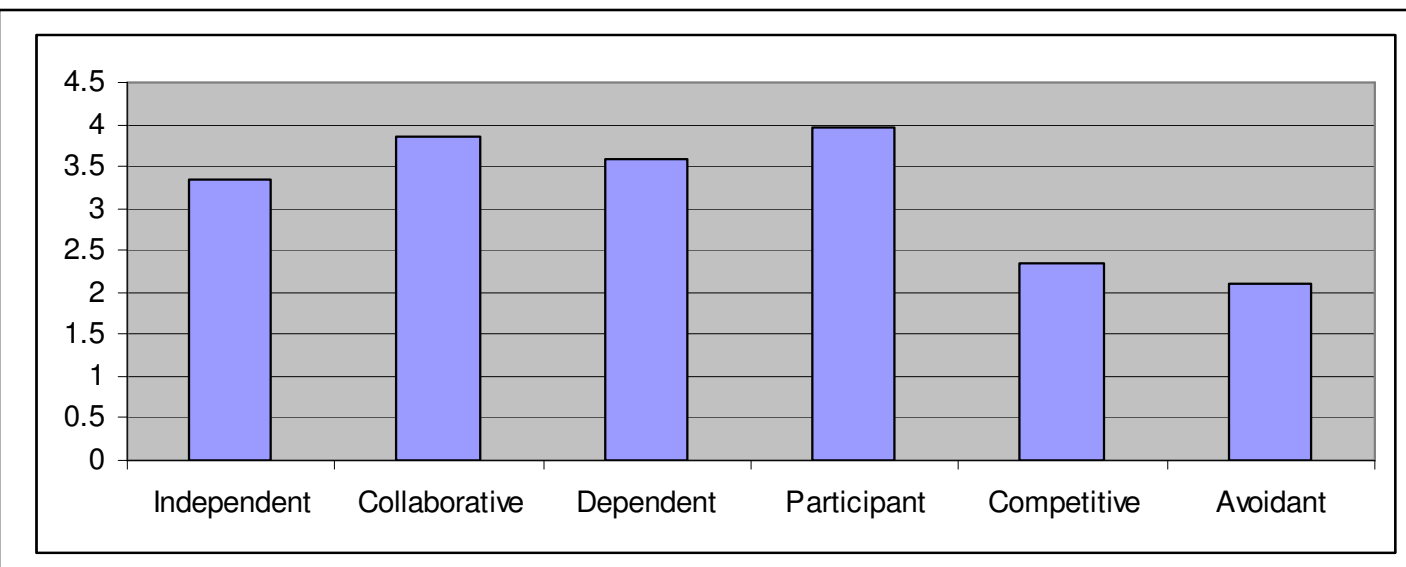

Figure 3. Learning Styles of Students at Pre-test

of unequal cell sizes. Figure 3 shows the preferred learning styles assessed through the pre-test.

Although the pre-test showed students scoring high in the Collaborative and Participant styles, we were hopeful of increasing the scores in these areas through instructional intervention and the use of technology. Similarly, we wanted to increase students' Independent style preference. 
After implementing the instructional strategies and using Blackboard as described earlier, posttest students showed highest scores in Independent, Collaborative, and Participant learning styles. A T-test analysis of the pre- and post-test scores indicated that there was a significant increase in the Independent, Collaborative, and Participant learning styles over the course of the semester. Table 5 shows scores for the learning styles from the pre- and post-test assessments.

\section{Discussion}

The purpose of this study was to examine the influence of instructional methods and information technology on the learning styles of students. The assessments suggest that students do

Table 5. Changes in Student Learning Styles from Pre-test to Post-test

\begin{tabular}{|l|c|c|}
\hline \multicolumn{1}{|c|}{$\begin{array}{c}\text { Learning } \\
\text { Styles }\end{array}$} & Pre-test & Post-test \\
\hline Independent & 3.34 & $3.43^{*}$ \\
\hline Collaborative & 3.86 & $3.99 *$ \\
\hline Dependent & 3.58 & 3.68 \\
\hline Participant & 3.95 & $4.06^{*}$ \\
\hline Competitive & 2.35 & 2.33 \\
\hline Avoidant & 2.11 & 2.19 \\
\hline \multicolumn{3}{|c|}{ * Significant at $\mathbf{p}<.05$ level } \\
\hline
\end{tabular}
exhibit a preference for learning styles, corroborating earlier research (Andrews, 1981; Grasha 1996; Hruska-Riechmann \& Grasha 1982; McKeachie 1995).

Additionally, we were attempting to determine if students' learning styles do change as a result of instructional methods and information technology. In the study, instructional methods and technology were designed to accommodate the different learning styles of students, with activities also being structured in a way to help students strengthen their less dominant learning style. The results indicate that at pre-test, most students preferred a Participant learning style. They also scored high on Collaborative and Dependent learning styles.

For the courses, classroom activities and processes were designed to help all students strengthen their Independent, Collaborative, and Participatory learning styles. After participating in class activities - supported with technology—students showed a significant increase in the Independent, Collaborative, and Participatory learning styles, suggesting that learning styles can change through specific instructional intervention and the appropriate use of technology. This is an important finding because it shows that instructors can help students develop skills to become active participants in the learning process and to develop collaborative skills. The data also shows that students are able to strengthen or change a learning preference, as in the instance of the significant change from being dependent learners to independent learners.

\section{Conclusion}

This study moves beyond looking only at teaching styles, learning styles, or technology. Instead it explores the use of an integrated approach by combining all three dimensions in the teachinglearning context (instructional methods, learning styles, and information technology). The data from the study suggest that instructional strategies along with appropriate use of information technology can impact student learning styles.

It is a preliminary study and the results of this study have limited generalizability. The sample of the study included both undergraduate and graduate students. Several studies have indicated that there are differences in learning styles based on age, gender, major, and graduate/undergraduate status. This study did not take into account these factors. These differences can be examined in future studies. In addition, an important research question to examine would be to examine the effect of integrating learning style assessment on student learning. In other words, how does an awareness of student learning styles along with specific instructional strategies and use of technology affect student learning and achieving specific learning outcomes? The significance of 
changing learning styles increases in the context of improving student learning. Additional research may show how an understanding of learning styles, along with specific instructional strategies and information technology, enhances student learning and performance.

This study enhances our understanding of the teaching-learning process by showing evidence that what we do as teachers, along with our use of technology, can impact student learning preferences, a critical factor in student learning. In the current outcome-based educational environment, an understanding of how students learn and how we as instructors can increase student learning has become more important. As we better understand the teaching-learning process, we can become significant factor in promoting greater student satisfaction and achievement, ultimately helping students become more successful in their schooling and in their lives.

\section{References}

Alavi, M., \& Leidner, D.E. (2001). Research commentary: Technology- mediated learning: A call for greater depth and breadth of research. Information Systems Research, 12 (1), 1-10.

Andrews, J. A. (1981). Teaching format and student style: Their interactive effects on learning. Research in Higher Education, 14, 161-178.

Argyris, C. (1991, May-June). Teaching smart people how to learn. Harvard Business Review, 99-109.

Bartlett, J. E. \& Kotrlik, J. W. (2001). Analysis of the use of learning resources and self-directed learning by secondary Pennsylvania business educators. The Delta Pi Epsilon Journa,l 43 (3), 123-136.

Bonwell, C. C. \& Eison, J. A. (2000). Active learning: Creating excitement in the classroom. New York: John Wiley.

Corno, L., \& Snow, R.E (1986). Adapting teaching to individual differences among learners. In M.C. Wittrock (Ed.), Handbook of research on teaching ( $3^{\text {rd }}$ ed.). New York: Macmillan.

Dunn, R. (1986). Learning style: State of the science. Theory into Practice, 24 (1), 10-19.

Ellerman, D., Denning, S., \& Hanna, N. (2001). Active learning and development assistance. Journal of Knowledge Management 5 (2), 171-180.

Farrignton, G.C. (1999). The new technologies and the future of residential undergraduate education. In R.N. Katz and associates (Eds.), Dancing with the devil (pp. 73-94). San Francisco, CA: Jossey-Bass.

Felder, R. (1993). Reaching the second tier: Learning and teaching styles in college science education. Journal of College Science Teaching, 23 (5), 286-290.

Felder, R.M., \& Silverman, L.K. (1988). Learning and teaching styles in engineering education. Engineering Education, 78 (7), 674-681.

Glassop, L. I. (2002). The organizational benefits of teams. Human relations, 55 (2), 225-249.

Grasha, A. (1996). Teaching with style. Pittsburgh, PA: Alliance.

Hruska-Riechmann, S., \& Grasha, A.F. (1982). The Grasha-Riechmann student learning style scales: Research findings and applications. In J. Keefe (Ed.), Student learning styles and brain behavior. Reston, VA: NASSP.

Knowles, M. S. (1975). Self-directed learning: A guide for learners and teachers. New York: Cambridge Books.

Kolb, D.A. (1984). Experiential learning: Experience as the source of learning and development. Englewood Cliffs, NJ: Prentice-Hall.

McKeachie, W. J. (1995). Learning styles can become learning strategies. The National Teaching and Learning Forum, 4 (6), 1-3.

Michaelsen, L. K., A. B. Knight, \& L. D. Fink. (2003). Team-based learning: A transformative use of small groups. Westport, CT: Praeger. 
Assessing the Impact of Instructional Methods and Information Technology

Montgomery, S.M. \& Groat, L.N. (1998). Student learning styles and their implications for teaching. Re trieved from http://www/crlt.umich.edu/occ10.html

O’ Connor, T. (1997) Using learning styles to adapt technology for higher education Retrieved from http://web.indstate.edu/ctl/styles/learning.html\#STYLES

Ross, J.L., \& Schulz, R.A (1999). Using the World Wide Web to accommodate diverse learning styles. College Teaching, 47 (4), 123-129.

Sarasin, L.C. (1998). Learning styles perspectives: Impact in the classroom. Madison, Wisconsin: Atwood Publishing.

Sashkin, M. \& Sashkin, M. G. (1994). The new teamwork: Developing and using cross-function teams. New York: American Management Association.

Schroeder, C.C. (1996). New Students-new learning styles. Retrieved from http://www.virtualschool.edu/mon/Academia/KierseyLearningStyles.html

Soles, C. \& L. Moller (2001). Myers-Briggs type preferences in distance learning education. International Journal of Educational Technology, 2 (2).

Zemke, R. 1993. Rethinking the rush to team up. Training, 30 (11), 55-61.

\section{Biographies}

Poonam Kumar is an Associate Professor in the Department of Elementary, Early Childhood and Special Education at Saginaw Valley State University. She holds a doctorate in Special Education from the University of Memphis. She has published several articles on technology integration in teacher education and serves as a reviewer for the journal Educational Technology \& Society.

Anil Kumar is an Assistant Professor in the Business Information Systems Department at Central Michigan University. He has a doctorate in Management Information Systems from the University of Memphis. His current research focuses on global information technology and elearning. He is active in several professional organizations and is on the editorial board of the Journal of Global Information Technology Management.

Karl L. Smart is an Assistant Professor in the Business Information Systems Department at Central Michigan University. He has published several articles on user-centered design and issues of quality in professional communication. His current research focuses on applying information design and quality to the Internet. 